\title{
Plains Prickly Pear Response to Fire: Effects of Fuel Load, Heat, Fire Weather, and Donor Site Soil
}

\author{
Lance T. Vermeire ${ }^{1}$ and Aaron D. Roth ${ }^{2}$
}

Authors are ${ }^{1}$ Rangeland Ecologist, USDA-Agricultural Research Service, Fort Keogh Livestock and Range Research Laboratory, 243 Fort Keogh Road, Miles City, MT 59301, USA; and ${ }^{2}$ Soil Conservationist, USDA-NRCS, 721 S Canyon Blvd, John Day, OR 97845, USA.

\begin{abstract}
Plains prickly pear (Opuntia polyacantha Haw.) is common throughout the Great Plains and often becomes detrimental to agricultural production on noncultivated lands. We examined direct fire effects on plains prickly pear and mechanisms of tissue damage to facilitate development of fire prescriptions. Cladodes from clones on three soils (claypan, gravelly, silty) were subjected to fire with two weather conditions (moderate, severe) at four fuel loads $\left(1500,3000,4500\right.$, and $6000 \mathrm{~kg} \cdot \mathrm{ha}{ }^{-1}$ ) and a nonburned control. Fire was simulated with field-collected grass, and heat was measured using thermocouples at the soil surface and $8 \mathrm{~cm}$ above. Plants were maintained in a greenhouse and monitored for cladode mortality or growth. Cactus response to fire was examined in a field experiment with four nonburned and four summer-burned 0.75-ha plots. Some plants from each treatment sprouted new cladodes. Donor site soil and fire weather effects were limited to mass of new sprouts as they interacted with fuel load. Fire under any condition reduced cactus mass and survival. Reduction in cactus mass increased from $42 \%$ with $1500 \mathrm{~kg} \cdot \mathrm{ha}^{-1}$ to $92 \%$ with fuel loads of $3000 \mathrm{~kg} \cdot \mathrm{ha}^{-1}$ or more. Fuel load, duration of heat, maximum temperature, and degree-seconds were each positively related to mortality, but duration of heat greater than $60^{\circ} \mathrm{C}$ was the best predictor. Plant mortality was $15 \%$ in the field, but number of live cladodes was initially reduced $91 \%$. After one year, number of live cladodes in burned plots was $43 \%$ of that in nonburned plots because burned plants sprouted more new cladodes than nonburned plants. Insect and browsing damage occurred on $83 \%$ of cladodes in burned plots and only $8 \%$ for nonburned plots. Lack of fire weather effects suggests prickly pear control can be achieved under broad fire prescriptions, given the amount of combustible fuel is adequate.
\end{abstract}

\section{Resumen}

Opuntia polyancantha Haw. es una especie común a lo largo de las Grandes Planicies de América del Norte y frecuentemente se torna perjudicial para la producción agropecuaria en tierras no-cultivadas. Se examinaron los efectos directos del fuego sobre $O$. polyancantha y los mecanismos de daño a sus tejidos a fin de facilitar el desarrollo de prescripciones de quemas. Pencas de clones de tres suelos (arcilloso, pedregoso, limoso) fueron sometidas al fuego bajo dos condiciones meteorológicas (moderada, severa) con cuatro cargas de combustible $\left(1500,3000,4500\right.$, y $\left.6000 \mathrm{~kg} \cdot \mathrm{ha}^{-1}\right)$. El fuego se simuló con pasto cosechado en el campo y el calor se midió utilizando termocuplas en la superficie del suelo y $8 \mathrm{~cm}$ por encima de la misma. Las plantas se mantuvieron en un invernáculo y fueron monitoreadas para determinar la mortalidad o el crecimiento de las pencas. La respuesta del cactus al fuego fue examinada en un experimento de campo con cuatro testigos sin quemar y cuatro quemas de verano en parcelas de 0,75 ha. Algunas plantas en cada tratamiento produjeron pencas nuevas. Los efectos del suelo del sitio de cosecha y del fuego que interactuaron con la carga de combustible influenciaron de modo limitado la masa de brotes nuevos. El fuego bajo cualquiera de las situaciones estudiadas redujo la masa y la sobrevivencia de cactus. La reducción en la masa de cactus aumentó desde el $42 \%$ con cargas de $1500 \mathrm{~kg} \cdot \mathrm{ha}^{-1}$ al $92 \%$ con cargas de $3000 \mathrm{~kg} \cdot \mathrm{ha}^{-1} \mathrm{o}$ más. La carga de combustible, la duración del calor, la temperatura máxima, y los grados-segundo correlacionaron positivamente con la mortalidad, pero la duración de temperaturas superiores a los $60^{\circ} \mathrm{C}$ fue el mejor predictor. La mortalidad de plantas en el experimento de campo fue del $15 \%$, pero el número de pencas vivas se redujo inicialmente en un $91 \%$. Luego de un año, el número de pencas vivas en las parcelas quemadas fue un $43 \%$ comparado con las parcelas testigo porque las plantas quemadas produjeron más pencas nuevas que las plantas no-quemadas. Se constataron daños por insectos y ramoneo en el $83 \%$ y $8 \%$ de las pencas en parcelas quemadas y testigo, respectivamente. La ausencia de efectos del tipo de fuego y de las condiciones meteorológicas sugiere que se puede lograr el control de O. polyacantha con una amplia gama de prescripciones de fuego, siempre y cuando las condiciones de combustible sean las adecuadas.

Key Words: duration of heat, logistic regression, maximum temperature, mortality, Opuntia, prescribed fire

Mention of trade names or commercial products in this publication is solely for the purpose of providing specific information and does not imply recommendation or endorsement by the US Department of Agriculture (USDA).

At the time of the research, A.D.R. was Rangeland Technician, USDA-Agricultural Research Service, Fort Keogh Livestock and Range Research Laboratory, 243 Fort Keogh Road, Miles City, MT 59301, USA.

Correspondence: Lance Vermeire, Fort Keogh Livestock and Range Research Laboratory, USDA-Agricultural Research Service, 243 Fort Keogh Road, Miles City, MT 59301, USA. Email: Lance.Vermeire@ars.usda.gov

Manuscript received 10 November 2010; manuscript accepted 7 April 2011. 


\section{INTRODUCTION}

Prickly pears (Opuntia Mill.) make up the most diverse genus of the Cactaceae family and are prominent throughout much of the western hemisphere where they evolved, with 31 species and about a dozen varieties in the United States alone (Rebman and Pinkava 2001). Prickly pears are an important food source for people and provide habitat for some species of wildlife (Russell and Felker 1987; Singh and Singh 2003; Snyman 2006). However, they can reduce diversity and suitability for agricultural production when abundant, particularly where they have been introduced. Introductions have had devastating effects in the Mediterranean (Vila et al. 2003), Australia (Freeman 1992), East Africa, and South Africa (Foxcroft et al. 2004).

Plains prickly pear (Opuntia polyacantha Haw.) is among the most common and widely distributed Opuntia sp. throughout the Great Plains and western United States. The protective spines of plains prickly pear discourage large herbivores from grazing in its vicinity (Turner and Costello 1942; Bement 1968; Price et al. 1985), providing a refuge for grazing-sensitive species when grazing is intense (Rebollo et al. 2002, 2005). However, when the cacti are abundant, this protective mechanism can reduce forage availability and increase the probability of injury to large herbivores. Grazing management appears to have little effect on prickly pear (Houston 1963; Bement 1968; Milchunas et al. 1989), but livestock exclusion has increased abundance (Hart and Ashby 1998).

Natural fluctuations in prickly pear abundance appear related to weather, insects, and fire. Prickly pears often become more abundant following persistent drought (Cook 1942; Turner and Costello 1942; Glendening 1952; Houston 1963) because they have extensive root systems capable of rapidly taking up water and storing it in cladodes for use when water is limited (Turner and Costello 1942; Dougherty et al. 1996; Snyman 2005, 2006). Insects can reduce prickly pear abundance (Weaver and Albertson 1940; Houston 1963; Lockwood and Bomar 1992) and have been credited as the primary control agent of prickly pear invasions in Australia (Freeman 1992).

Fire is a natural process that, to varying degrees, reduces dominance of cacti (Heirman and Wright 1973; Bunting et al. 1980; Martin 1983; Thomas and Goodson 1992; Ansley and Castellano 2007). Neither the mechanisms of first-order fire effects on cacti in general nor tissue response to heat from fire are well defined (Stephan et al. 2010). Cacti are known to tolerate hotter conditions than most vascular plants (Smith et al. 1984) and may avoid fire by inhabiting sites with low probability of sustaining fire. Cacti also resist combustion and heat transfer, and some are capable of sprouting from undamaged tissues. Plains prickly pear appears well adapted to fire and disturbance in general because it produces abundant seed and sprouts from roots and stolons, and detached cladodes can grow roots (Harvey 1936; Turner and Costello 1942; Reyes-Aguero et al. 2006). Plains prickly pear has been reduced by fire (Augustine and Milchunas 2009). However, the conditions that best explain direct fire effects on plains prickly pear or how changes in fire conditions affect probability of mortality for individual cladodes or entire plants are unknown.
Further, distinctions between mortality of individual cladodes and entire plants are important because the sprouting ability of plains prickly pear has ramifications for the rate of population recovery following fire.

Fireline intensity and maximum temperature are two of the most common measures of heat that are recorded to explain plant response to fire because they are relatively easy to measure. Fireline intensity (Byram 1959) is a measure of fire behavior and often relates closely to fire effects on shrub and tree canopies, but has limitations for plants nearer the soil surface (Keeley 2009). Fire effects on low-growing species will likely be better predicted from measures of heat near the soil surface, where meristems are located, rather than measures more closely related to flame length and convective heat. Cacti rarely combust completely because they thicken at the base with age (Stephan et al. 2010) and have high water content and a small surface-to-volume ratio that impede heat transfer from surrounding combustible fuels. Therefore, maximum temperature alone may not adequately predict fire effects on cactus. Survival is likely determined by duration of lethal temperatures or the integration of temperature and duration.

The amount of fuel available for combustion (hereafter referred to as fuel load) is positively related to potential energy released (Byram 1959), duration of heat, and maximum temperature (Stinson and Wright 1969) and could also provide acceptable predictions of fire effects on cactus. Similarly, fire prescriptions including hotter, drier ambient conditions have been suggested to increase fire intensity, duration of heat, and cactus mortality (Ansley and Castellano 2007).

Our objectives were to determine donor site soil, fire weather, fuel load, and heat dosage effects on plains prickly pear survival and sprouting and to identify the best predictors of first-order fire effects. We hypothesized that 1) cactus resistance to fire would increase from plants originating on claypan soils to those from silty soils and be greatest for plants from gravelly soils. Claypan soils have light fuel loads, suggesting limited historical fire disturbance. Heavier fuel loads on silty and gravelly soils indicate greater probability that established cacti had been exposed to fire. Greater exposure to fire on these soils and the relative instability of gravelly soils may be expected to favor selection of individual plants with a greater propensity to sprout following disturbance. We also hypothesized that 2) severe fire weather conditions would cause greater mortality and reduction of cactus biomass than moderate fire weather conditions by increasing heat dosage. We hypothesized that 3 ) cactus mortality would increase with fuel load and each measure of heat dosage. Finally, we hypothesized that 4) duration of temperatures at the soil surface greater than $60^{\circ} \mathrm{C}$ would be the best predictor of cactus response to fire relative to fuel load, maximum temperature, or degree-seconds at the soil surface, and duration of heat, maximum temperature, or degree-seconds $8 \mathrm{~cm}$ above the soil surface.

\section{METHODS}

Plains prickly pear cladodes were collected from four clones (10 cladodes per clone) on each of three soil types on the Fort Keogh Livestock and Range Research Laboratory near Miles 
City, Montana (lat $46^{\circ} 22^{\prime} 55^{\prime \prime} \mathrm{N}$, long $105^{\circ} 57^{\prime} 20^{\prime \prime} \mathrm{W}$ ). After each cladode was rooted in its own pot, it was exposed to fire from a randomly assigned combination of five fuel loads $(0$, $1500,3000,4500$, or $6000 \mathrm{~kg} \cdot \mathrm{ha}^{-1}$ ) and two fire weather conditions (moderate or severe) by clone, with four replications for each treatment combination. Thermocouples recorded maximum temperature, duration of heat greater than $60^{\circ} \mathrm{C}$, and degree-seconds above a base temperature of $60^{\circ} \mathrm{C}$ at the soil surface and $8 \mathrm{~cm}$ above the surface. This design allowed us to simultaneously evaluate how fuel load and fire weather affected heat dosage and determine which measure of heat best explained plant response to fire for cacti established on three soil types.

\section{Cladode Collection}

Plants were selected from claypan, gravel, and silty ecological sites. Soils on the claypan site were a Gerdrum-Creed complex clay loam (fine, smectitic, frigid Torrertic Natrustalfs) with 0$2 \%$ slope. The gravel site was a Vendome gravelly sandy loam (sandy-skeletal, mixed, frigid Aridic Haplustolls) with 8-35\% slope. The silty site was a Brushton silt loam (fine-silty, mixed, superactive, frigid Aridic Argiustolls) with $0-4 \%$ slope. The 72 yr average temperature is $7.8^{\circ} \mathrm{C}$, ranging from $-8.4^{\circ} \mathrm{C}$ during January to $23.7^{\circ} \mathrm{C}$ in July. Mean annual precipitation for the same period is $338 \pm 89 \mathrm{~mm}$.

From each site, four prickly pear clones were selected that were clearly separate from other clones and had 14 to 16 cladodes connected at the base only to a previous-year cladode. These selection criteria were established to ensure cladodes were clones and that there was an adequate number of cladodes to select 10 that were healthy, similar to each other in size, and to allow collection of replacement cladodes in case some were damaged or did not establish well after collection. Each cladode was cut using a disinfected knife and placed in a paper bag. Cladodes were collected in late April and placed in a wellventilated room. Three days later all cladodes were measured and weighed. Greatest thickness, longest length, and perpendicular length were measured to the nearest $0.01 \mathrm{~mm}$ using a Mitutoyo Absolute Digimatic caliper, and cladodes were weighed to the near $0.01 \mathrm{~g}$.

A soil mixture was made from $60 \%$ Glacier Gold potting soil and $40 \%$ washed sand. Soil mixture was added to $2.3-\mathrm{L}$ circular pots (15-cm diameter) and settled just below the lip. Cladodes callused $21 \mathrm{~d}$ after they were cut, and one was planted per pot in a vertical position with $25 \%$ of the cladode below the soil and oriented in the same direction in the greenhouse. The soil surface around cladodes was misted $11 \mathrm{~d}$ after planting. Cladodes were watered each week until exposed to fire. The last watering occurred $4 \mathrm{~d}$ before fire treatment with severe weather conditions and $8 \mathrm{~d}$ before treatment with moderate weather conditions. The last scheduled watering for cacti burned with moderate conditions was canceled because it was $1 \mathrm{~d}$ before fires and soils required more time to dry.

\section{Burn Cage}

Grassland fires were simulated outdoors by burning field-cured grass in a cage (Vermeire and Rinella 2009) containing one cladode from each soil type under two contrasting temperature and humidity conditions on 25 and 29 August 2008. Moderate weather conditions were defined as temperatures between $15^{\circ} \mathrm{C}$ and $25^{\circ} \mathrm{C}$ with relative humidity between $30 \%$ and $45 \%$, and severe burning conditions were defined as temperatures hotter than $30^{\circ} \mathrm{C}$ and relative humidity less than $35 \%$. The fire cage was $1-\mathrm{m}$ long, $0.5-\mathrm{m}$ wide, $0.5-\mathrm{m}$ tall, and elevated $30 \mathrm{~cm}$ above ground level. The cage was constructed in a steel frame with $1-\mathrm{cm}$ wire mesh walls and a $3-\mathrm{mm}$ thick steel plate floor. Three circles slightly smaller than the pot size were cut in the floor allowing the cladodes to be inserted through the hole with the pots resting against the bottom of the metal plate. The center of pots was positioned $65 \mathrm{~cm}$ from the front edge of the cage, allowing a passing fire front. One pot from each soil type was randomly placed in each slot for each replicated fire treatment. Three type-K thermocouples insulated with ceramic fiber and Inconel braidings (Omega Engineering, Stamford, CT) were suspended $8 \mathrm{~cm}$ above the soil, representing the average midpoint of cladodes, and three thermocouples were fixed on the soil surface, with one in each position per pot. Thermocouples were connected to a Campbell Scientific 21X micrologger with a SM4M Storage module (Campbell Scientific, Logan, UT), which was connected to a laptop computer to record time-temperature profiles at 1-s intervals during treatment. Thermocouple data were used to determine duration of temperatures greater than $60^{\circ} \mathrm{C}$ (duration), maximum temperature, and the sum of the products of time and temperature greater than $60^{\circ} \mathrm{C}$ (degree-seconds) to estimate heat dosage. Although lethal temperatures vary with a number of conditions, $60^{\circ} \mathrm{C}$ is commonly used for plant tissue (Wright and Bailey 1982) and was selected in this study to describe potentially lethal temperatures. Heat dosage data were summarized by thermocouple within burn.

The fuel source was crested wheatgrass (Agropyron cristatum [L.] Gaertn.) cut from nongrazed stands during early August with a sickle bar mower. After mowing, the grass was raked, dried to a constant weight at $60^{\circ} \mathrm{C}$, then weighed in 75 , 150,225 , and $300 \mathrm{~g}$ increments to obtain prescribed fuel loads. After soil surface thermocouples were positioned, the grass was evenly spread on the floor of the cage by hand. The suspended thermocouples were then positioned directly in line with the cladode. A line of fuel (60:40 diesel:gasoline) was poured at the edge of the cage then ignited for an even fire front, and a fan was used to provide a steady rate of spread with wind speeds of at least $2.2 \mathrm{~m} \cdot \mathrm{s}^{-1}$ if ambient wind speed was slower than that rate. Pots were transported to the green house after all smoldering had ceased and temperatures dropped below $50^{\circ} \mathrm{C}$.

\section{Greenhouse Cladode Evaluation}

Greenhouse temperatures were set to $21.1^{\circ} \mathrm{C}$ and $10.0^{\circ} \mathrm{C}$ day and night temperatures, respectively. Severe weather cladodes were watered $3 \mathrm{~d}$ after burning, and moderate weather cladodes were watered $4 \mathrm{~d}$ after burning. Each pot was given $5.5 \mathrm{~mm}$ once each week until cladodes were harvested 10 December 2008. Mortality was determined to have occurred for individual cladodes if there was no green tissue by the harvest date, and whole plant mortality declared if the original cladode was dead and there were no live sprouts. Cladodes were harvested by cutting all roots from the cladode and removing as much soil from the cladode as possible. Each new cladode attached aboveground or belowground to the original 
Table 1. Fuel load effects on duration of heat, maximum temperature, and degree-seconds at the soil surface and $8 \mathrm{~cm}$ above soil across moderate and severe weather conditions and standard errors of the differences (SED). Means represent 24 individual burn cage fires per fuel load.

\begin{tabular}{|c|c|c|c|c|c|c|}
\hline \multirow[b]{2}{*}{ Fuel load $\left(\mathrm{kg} \cdot \mathrm{ha}^{-1}\right)$} & \multicolumn{3}{|c|}{ Soil surface } & \multicolumn{3}{|c|}{$8 \mathrm{~cm}$ above soil } \\
\hline & $\begin{array}{l}\text { Duration } \\
\left(\mathrm{s}>60^{\circ} \mathrm{C}\right)\end{array}$ & $\begin{array}{l}\text { Maximum } \\
\left({ }^{\circ} \mathrm{C}\right)\end{array}$ & $\begin{array}{c}\text { Degree-seconds } \\
\left({ }^{\circ} \mathrm{C} \cdot \mathrm{s}>60^{\circ} \mathrm{C}\right)\end{array}$ & $\begin{array}{l}\text { Duration } \\
\left(\mathrm{s}>60^{\circ} \mathrm{C}\right)\end{array}$ & $\begin{array}{c}\text { Maximum } \\
\left({ }^{\circ} \mathrm{C}\right)\end{array}$ & $\begin{array}{c}\text { Degree-seconds } \\
\left({ }^{\circ} \mathrm{C} \cdot \mathrm{s}>60^{\circ} \mathrm{C}\right)\end{array}$ \\
\hline 1500 & $81 d^{1}$ & $299 \mathrm{C}$ & $6454 d$ & $48 \mathrm{c}$ & $193 \mathrm{C}$ & $2862 \mathrm{c}$ \\
\hline 3000 & $146 \mathrm{c}$ & $339 \mathrm{c}$ & $11592 \mathrm{c}$ & $75 \mathrm{~b}$ & $355 \mathrm{~b}$ & $8478 \mathrm{~b}$ \\
\hline 4500 & $198 \mathrm{~b}$ & $456 \mathrm{~b}$ & $17941 \mathrm{~b}$ & $85 a b$ & $358 \mathrm{~b}$ & $9901 \mathrm{~b}$ \\
\hline 6000 & $250 \mathrm{a}$ & 526 a & $25989 \mathrm{a}$ & $98 \mathrm{a}$ & 459 a & $13811 \mathrm{a}$ \\
\hline SED & 19 & 32 & 1895 & 7 & 30 & 1218 \\
\hline
\end{tabular}

${ }^{1}$ Within columns, means followed by the same letter do not differ $(\alpha=0.05)$.

cladode was also cut and individually weighed. Nine pots from each of the fuel treatment levels were randomly selected to be root washed, with the restriction that only pots with a new cladode were considered and samples were blocked based on fuel load. Samples were washed through a $2-\mathrm{mm}$ and $1-\mathrm{mm}$ soil sieve. Any roots were collected in an $850-\mu \mathrm{m}$ sieve and washed to remove any attached soil. Samples were placed in metal tins and oven dried at $105^{\circ} \mathrm{C}$ for 48 hours. Samples were then ashed at $550^{\circ} \mathrm{C}$ for 24 hours to obtain an ash-free organic matter weight.

\section{Field Observations}

Eight 0.75 -ha plots were randomly assigned to summer fire or no fire treatments on a silty ecological site (lat $46^{\circ} 23^{\prime} 56^{\prime \prime} \mathrm{N}$ long $105^{\circ} 57^{\prime} 02^{\prime \prime} \mathrm{W} ; 815 \mathrm{~m}$ a.s.l.) with Pinehill loam soil (fine, montmorillonitic Typic Eutroboralfs). The site had a history of grazing by cattle, but neither treatment was grazed by livestock the year before or after fire. Within each plot, 10 cacti with multiple live cladodes were systematically selected along paced transects, permanently marked with flagging and an aluminum identification tag, and the number of live cladodes per plant was recorded. Fuel loads were estimated by clipping standing crop and collecting litter from $20,0.25-\mathrm{m}^{2}$ quadrats per plot that were systematically selected along paced transects. Fire treatment plots were burned 24 August 2004 with a mean fuel load of $1569 \mathrm{~kg} \cdot \mathrm{ha}^{-1}$, ambient temperature of $26^{\circ} \mathrm{C}, 34 \%$ relative humidity, and $8-31 \mathrm{~km} \cdot \mathrm{h}^{-1}$ winds. High fuel continuity allowed for complete fire coverage of all vegetated portions of each plot. Cladodes were counted again on 25 October, 18 April, and 10 August following fire, separately recording green, brown, and partially browned cladodes. On the final measurement, number of cladodes that were damaged by browsing or insects was also noted.

\section{Statistical Analysis}

Models evaluating heat measures and cladode number and mass were analyzed using SAS MIXED ANOVA (Littell et al. 1996). Duration, maximum temperature and degree-seconds models included main effects of fuel load (1500-6000 $\mathrm{kg} \cdot \mathrm{ha}^{-1}$ ) and fire weather (moderate and severe) as well as their interaction. Laboratory models of cladode number and weight contained terms for donor site soil, fire weather, fuel load (including nonburned control), and their interactions. Initial cladode mass, thickness, area, and surface-to-volume ratio were tested as potential covariates with SAS MIXED ANCOVA, but found insignificant in each case. Ranges and coefficients of variation (CV) were reported for morphological measurements. Root organic matter was assessed by fuel load alone. Numbers of live and damaged cladodes in the field were analyzed for differences between summer-burned and nonburned treatments using SAS MIXED ANCOVA for a completely randomized design (Littell et al. 1996). Live cladodes were analyzed with sampling period as a repeated measure, whereas damaged cladodes were assessed only for the final sampling period. Pretreatment cladode counts were used as a covariate for field models. Soil surface and above soil measurements of duration, maximum temperature and degreeseconds, and fuel load were each tested as predictor variables for original cladode and whole plant mortality with logistic regression using SAS LOGISTIC (Hosmer and Lameshow 2000; Menard 2002). Significance for all tests was declared at $P \leq 0.05$. Standard errors are reported following means in text as $\pm \mathrm{SE}$.

\section{RESULTS}

Severe weather conditions averaged an ambient temperature of $35.5 \pm 1.1^{\circ} \mathrm{C}$ and relative humidity of $23 \pm 3 \%$. Moderate conditions averaged an ambient temperature of $22.0 \pm 1.0^{\circ} \mathrm{C}$ and relative humidity of $37 \pm 3 \%$. Wind speeds were $4.7 \mathrm{~m} \cdot \mathrm{s}^{-1}$ during severe weather conditions and adjusted to $2.2 \mathrm{~m} \cdot \mathrm{s}^{-1}$ with a fan for moderate conditions because ambient wind speed was $1.7 \mathrm{~m} \cdot \mathrm{s}^{-1}$. Weather effects on heat measures were limited to duration and maximum temperature. Severe weather increased duration of heat (193 vs. $145 \pm 13$ s) but produced cooler maximum temperatures than moderate conditions (372 vs. $438 \pm 23^{\circ} \mathrm{C}$ ). Fuel moisture was low under both conditions but greater for severe $(3.25 \%)$ than moderate conditions $(1.85 \%)$ because the moisture reflected indoor storage conditions before burning rather than outdoor conditions at the time of fire. Fuel load was the primary driver of heat and all measures of heat increased with increasing fuel load (Table 1). Soil surface measures were more sensitive and generally greater than those at $8 \mathrm{~cm}$ above soil. Magnitude of change with increasing fuel load was greatest for degree-seconds and least for maximum temperature. The relative difference in soil surface heat between fires with 1500 and $6000 \mathrm{~kg} \cdot \mathrm{ha}^{-1}$ fuel loads was $402 \%$ for degree-seconds, 309\% for duration, and only $176 \%$ for maximum temperature.

None of the initial cladode mass and morphology measurements were significant covariates for any of the data tested. 
Table 2. Fuel load effects on original prickly pear cladodes, new cladodes, total live cladodes, and root organic matter (OM) per pot and standard errors of the differences (SED) following fires in a burn cage. Means represent 24 individual fires per fuel load.

\begin{tabular}{|c|c|c|c|c|c|c|}
\hline Fuel load $\left(\mathrm{kg} \cdot \mathrm{ha}^{-1}\right)$ & $\begin{array}{l}\text { Live original } \\
\text { cladode }(\%)\end{array}$ & $\begin{array}{c}\text { New cladodes } \\
\text { (no.) }\end{array}$ & $\begin{array}{l}\text { Live cladodes } \\
\text { (no.) }\end{array}$ & $\begin{array}{l}\text { Live original cladode } \\
(\mathrm{g})\end{array}$ & $\begin{array}{l}\text { Total live } \\
(\mathrm{g})\end{array}$ & $\begin{array}{l}\text { Root OM } \\
\text { (g) }\end{array}$ \\
\hline 0 & $75 a^{1}$ & $0.3 \mathrm{a}$ & $1.0 \mathrm{a}$ & $16.22 \mathrm{a}$ & $16.43 \mathrm{a}$ & $0.20 \mathrm{a}$ \\
\hline 3000 & $4 \mathrm{c}$ & $0.7 \mathrm{a}$ & $0.8 \mathrm{a}$ & $0.83 \mathrm{c}$ & $2.05 \mathrm{c}$ & $0.09 \mathrm{~b}$ \\
\hline 4500 & $0 \mathrm{c}$ & $1.0 \mathrm{a}$ & $1.0 \mathrm{a}$ & $0.00 \mathrm{c}$ & $1.23 \mathrm{c}$ & $0.07 \mathrm{~b}$ \\
\hline 6000 & $4 \mathrm{c}$ & $0.4 \mathrm{a}$ & $0.4 \mathrm{a}$ & $0.34 \mathrm{c}$ & $0.78 \mathrm{c}$ & $0.06 \mathrm{~b}$ \\
\hline
\end{tabular}

${ }^{1}$ Within columns, means followed by the same letter do not differ $(\alpha=0.05)$.

Therefore, neither initial cladode weight (7.50-84.54 g, $\mathrm{CV}=54 \%)$, thickness $(10-24 \mathrm{~mm}, \mathrm{CV}=20 \%)$, area $(11.5$ $\left.97.8 \mathrm{~cm}^{2}, \mathrm{CV}=47 \%\right)$, nor surface-to-volume ratio (1.25$2.77 \mathrm{~cm}^{-1}, \mathrm{CV}=19 \%$ ) affected plant response to fire with the range of data observed.

In the absence of fire, $25 \%$ of the original nonburned cladodes died over the duration of the experiment (Table 2), but plant mortality was $21 \%$ because some plants sprouted new cladodes. Exposure to fire with $1500-\mathrm{kg} \cdot \mathrm{ha}^{-1}$ fuel loads reduced survival of original cladodes another $29 \%$, and fuel loads of $3000-6000 \mathrm{~kg} \cdot \mathrm{ha}^{-1}$ reduced survival an additional $72 \%$ relative to nonburned plants. Root mass was reduced $58 \%$ by fire across all fuel loads. Some plants in each treatment produced new cladodes, but the average was less than one new cladode for each pot for all treatments, and no differences in total number of live cladodes were detected among fuel loads. Fuel load effects for biomass were similar to those on survival of original cladodes, with a $1500-\mathrm{kg} \cdot \mathrm{ha}^{-1}$ fuel load reducing original cladode and total live mass to $54 \%$ and $58 \%$ of nonburned weights, and 3000 to $6000 \mathrm{~kg} \cdot \mathrm{ha}^{-1}$ fuel loads reducing each to $2 \%$ and $8 \%$ of the nonburned weights, respectively. Although the number of new cladodes was similar across treatments, burned plants were able to partially compensate for fire-induced losses with heavier new cladodes, as indicated by new cladodes adding $1.10-1.74 \mathrm{~g}$ of live material to burned plants and only $0.70 \mathrm{~g}$ to nonburned plants (Table 2).

Fire weather conditions interacted with fuel load in their effect on new cladode biomass (Table 3). New cladode weight increased from nonburned plants to plants burned with a $4500 \mathrm{~kg} \cdot \mathrm{ha}^{-1}$ fuel load and was reduced back to nonburned levels with a $6000 \mathrm{~kg} \cdot \mathrm{ha}^{-1}$ fuel load when fire weather was moderate. When fire weather was severe, new cladode mass also increased then decreased with increasing fuel load, but the increase occurred with a fuel load of $3000 \mathrm{~kg} \cdot \mathrm{ha}^{-1}$. Fire weather and donor site soil also interacted in their effects on new cladode mass. New cladode mass was less following severe than moderate fire weather conditions for cacti from silty soils ( 0.39 vs. $1.20 \pm 0.38 \mathrm{~g})$, and cacti from gravelly soils produced more new cladode mass $(1.33 \mathrm{~g})$ than those from clayey $(0.45 \mathrm{~g})$ or silty soils when fire weather was severe. New cladode mass was the only cactus response variable affected by either fire weather or donor site soil.

Fuel load and each measure of heat were good predictors of original cladode mortality (Table 4). Goodness-of-fit statistics were inconsistent, with Hosmer and Lemeshow tests indicating models were not fit to data well for fuel load and both duration and degree-seconds $8 \mathrm{~cm}$ above soil, but all models produced reasonable max rescaled $r^{2}$ values. Validation of predicted mortality probabilities was good for all models, with $C$ statistics indicating models correctly assigned the greater probability for $83-93 \%$ of all possible paired observations of live and dead cladodes. Duration of heat at the soil surface provided the best predictions of cladode mortality, and confidence intervals were relatively small (Fig. 1A).

Fuel load and each measure of heat were significant predictors of whole plant mortality as well (Table 5). Predicted mortality for plants was considerably less than that for the original cladode because plants frequently sprouted new cladodes. Predictability of plant mortality was also substantially less than for original cladode mortality. C statistics decreased to a proportionally greater extent for heat measures $8 \mathrm{~cm}$ above soil than those at the soil surface. Duration of heat at the soil surface was the best predictor of plant mortality (Fig. 1B), closely followed by degree-seconds. The fuel load model was intermediate between heat measures at the soil surface and those $8 \mathrm{~cm}$ above (Fig. 2).

Summer fires in the field were preceded by the second driest spring $(80 \mathrm{~mm})$ in $70 \mathrm{yr}$ and followed by the fifth wettest spring (262 $\mathrm{mm}$ ) during the same period. Field data indicated August fire reduced the number of live cladodes per plant more than $91 \%$ by the first October following fire (Fig. 3). Fire effects were consistent during early growth in April. Cladode numbers increased during the growing season for nonburned and burned plants. However, burned plants grew more cladodes than

Table 3. Fuel load and fire weather (moderate averaged $22.0^{\circ} \mathrm{C}$ and $37 \%$ relative humidity, and severe averaged $35.5^{\circ} \mathrm{C}$ and $27 \%$ relative humidity) effects on total live weight of new cladodes produced following fires in a burn cage. Means represent 12 individual fires per fuel load.

\begin{tabular}{ccc}
\hline Fuel load $\left(\mathrm{kg} \cdot \mathrm{ha}^{-1}\right)$ & Moderate weather & Severe weather \\
\hline & $0.1 \mathrm{~A} \mathrm{~b}^{1}$ & $0.3 \mathrm{~A} \mathrm{~b}$ \\
1500 & $0.5 \mathrm{~A} \mathrm{~b}$ & $1.1 \mathrm{~A} \mathrm{ab}$ \\
3000 & $1.0 \mathrm{~A} \mathrm{ab}$ & $1.4 \mathrm{~A} \mathrm{a}$ \\
4500 & $1.9 \mathrm{~A} \mathrm{a}$ & $0.5 \mathrm{~B} \mathrm{ab}$ \\
6000 & $0.7 \mathrm{~A} \mathrm{~b}$ & $0.2 \mathrm{~A} \mathrm{~b}$ \\
\hline
\end{tabular}

${ }^{1}$ Within fuel loads, fire weather means followed by the same uppercase letter do not differ $(\alpha=0.05$, SED $=0.5)$.

${ }^{2}$ Within fire weather, fuel load means followed by the same lowercase letter do not differ $(\alpha=0.05$, SED $=0.5)$. 
Table 4. Logistic regression statistics for prediction of original cladode mortality from fuel load and measures of heat at the soil surface and $8 \mathrm{~cm}$ above soil following fires in a burn cage. Hosmer-Lemeshow is a goodness-of-fit test of predicted and actual response from partitioned data where probabilities of a greater $\chi^{2}$ exceeding 0.05 indicate a good fit. Max rescaled $r^{2}$ is an index of the coefficient of determination. $C$ statistic ranges from 0.5 (random) to 1.0 (perfect discrimination on response) for all pairs of opposite response, so 0.9 means the model correctly assigned higher probability for $90 \%$ of all pairs.

\begin{tabular}{|c|c|c|c|c|c|c|}
\hline Predictor variable $(x)$ & Slope $^{1}\left(\beta_{x}\right)$ & Intercept $\left(\beta_{0}\right)$ & $P>\chi^{2}\left(H_{0}: \beta_{x}=0\right)$ & Hosmer-Lemeshow & Max rescaled $r^{2}$ & C statistic \\
\hline Fuel load $\left(\mathrm{kg} \cdot \mathrm{ha}^{-1}\right)$ & 0.00107 & -1.1564 & $<0.0001$ & 0.0330 & 0.54 & 0.891 \\
\hline \multicolumn{7}{|l|}{ Soil surface } \\
\hline Duration $\left(\mathrm{s}>60^{\circ} \mathrm{C}\right)$ & 0.03190 & -1.5866 & $<0.0001$ & 0.4683 & 0.65 & 0.931 \\
\hline Maximum $\left({ }^{\circ} \mathrm{C}\right)$ & 0.00730 & -0.8353 & $<0.0001$ & 0.4661 & 0.42 & 0.836 \\
\hline Degree-seconds $\left({ }^{\circ} \mathrm{C} \cdot \mathrm{s}>60^{\circ} \mathrm{C}\right)$ & 0.000252 & -0.8292 & $<0.0001$ & 0.3922 & 0.51 & 0.893 \\
\hline \multicolumn{7}{|l|}{$8 \mathrm{~cm}$ above soil } \\
\hline Duration $\left(\mathrm{s}>60^{\circ} \mathrm{C}\right)$ & 0.04880 & -1.1483 & $<0.0001$ & 0.0209 & 0.52 & 0.884 \\
\hline Maximum $\left({ }^{\circ} \mathrm{C}\right)$ & 0.01130 & -1.2278 & $<0.0001$ & 0.5412 & 0.54 & 0.895 \\
\hline Degree-seconds $\left({ }^{\circ} \mathrm{C} \cdot \mathrm{s}>60^{\circ} \mathrm{C}\right)$ & 0.000456 & -0.7602 & $<0.0001$ & 0.0020 & 0.51 & 0.897 \\
\hline
\end{tabular}

${ }^{1}$ Probability of mortality $=e^{\left(\beta_{0}+\beta_{x}\right)} /\left(1+e^{\left(\beta_{0}+\beta_{x}\right)}\right)$.

nonburned plants, and $1 \mathrm{yr}$ after fire, the fire-induced reduction in cladode numbers was only $43 \%$. Reduction in the number of cladodes was considerably greater in the field than with the comparable $1500 \mathrm{~kg} \cdot \mathrm{ha}^{-1}$ fuel load tested in the burn cage. No plant mortality occurred in nonburned plots. Although cladode number was greatly reduced, most plants sprouted, and plant mortality was only $15 \%$ for burned plots, less than the $25 \%$ predicted by fuel load from burn cage data with a single cladode. Despite some recovery in cladode numbers, browsing or insect damage to cladodes was detected on $83 \%$ of burned plants and only $8 \%$ of nonburned plants.

\section{DISCUSSION}

\section{Donor Site Soil}

Support for the hypothesis that donor site soil would affect cactus resistance to fire was limited. New cladode mass was more than three times greater for cacti originating from gravelly soils when fire weather was severe. Although this response was in agreement with our predictions, we did not detect any soil effects for other measures of plains prickly pear response to fire. This indicates that donor site soil, and presumably disturbance history, may affect the ability of cactus to resist fire and should be explored further to determine whether such factors will explain additional variation in prickly pear response to fire or if populations are likely to become more resistant to repeated fire. Heat transfer is affected by soil texture and water content (Campbell et al. 1994, 1995; DeBano et al. 1998). Soil properties also affect fuel load, species composition, and the resulting probability of fireinduced mortality. However, the focus in this experiment was on donor site soil, and cacti were transferred to a common soil for fire treatments. Therefore, interpretation of results should be limited to donor site soil effects and not be taken to necessarily indicate differences or similarities in prickly pear response if exposed to fires across a range of soil conditions.

\section{Fire Weather}

The lack of weather effects on original cladode mortality, number of live cladodes, live cladode mass, or root mass led us to reject our hypothesis that severe fire weather would cause greater mortality and a reduction in cactus biomass. New cladode mass was the only measure of cactus response to fire that was affected by fire weather although weather had some effect on fire temperature. Others have indicated strong weather effects on plant response to fire (Ansley et al. 1998; Ansley and Castellano 2007). Temperature, relative humidity, and wind speed for the severe and moderate conditions were very similar to the summer and winter conditions examined by Ansley and Castellano (2007). In addition to stark differences in fire weather, to which Ansley and Castellano (2007) attributed fire effects on brownspine prickly pear (O. phaeacantha Engelm.), their summer fuel loads were about $48 \%$ greater than winter fuel loads. Given the similarity in weather conditions between experiments and the strong fuel load influence we observed, we suspect there is less disagreement between results of the two experiments than it appears.

Weather greatly influences fire behavior (Pyne et al. 1996), particularly in forested systems where fuel is abundant (Bessie and Johnson 1995). However, fire behavior does not always reflect heat dosage received near the soil surface (Keeley 2009), and neither air temperature nor relative humidity was shown to affect maximum temperature at the soil surface in grassland fuels (Britton and Wright 1971). Although we observed greater duration of heat with severe fire weather, maximum temperatures were greater under moderate conditions, and degreeseconds of heat were similar between weather conditions. Greater duration of heat with severe than moderate fire weather was in agreement with previous work $(\mathrm{McDaniel}$ et al. 1997). Greater maximum temperature with moderate conditions appears counterintuitive. Cooler temperatures have been reported for rapid wind-driven fires (Sparling and Smith 1966) because wind can dissipate heat. Wind speed was greater during the severe weather and occasionally gusty. Therefore, any tendencies for hotter ambient conditions to increase fire temperature may have been overwhelmed by the influence of wind pushing heat away. Although controlled tests of wind speed effects were not conducted, the importance of heat duration for cactus response indicates wind speed and relative direction of fire spread would likely be key factors. Grass fuels were drier under moderate than severe conditions. The dryness 

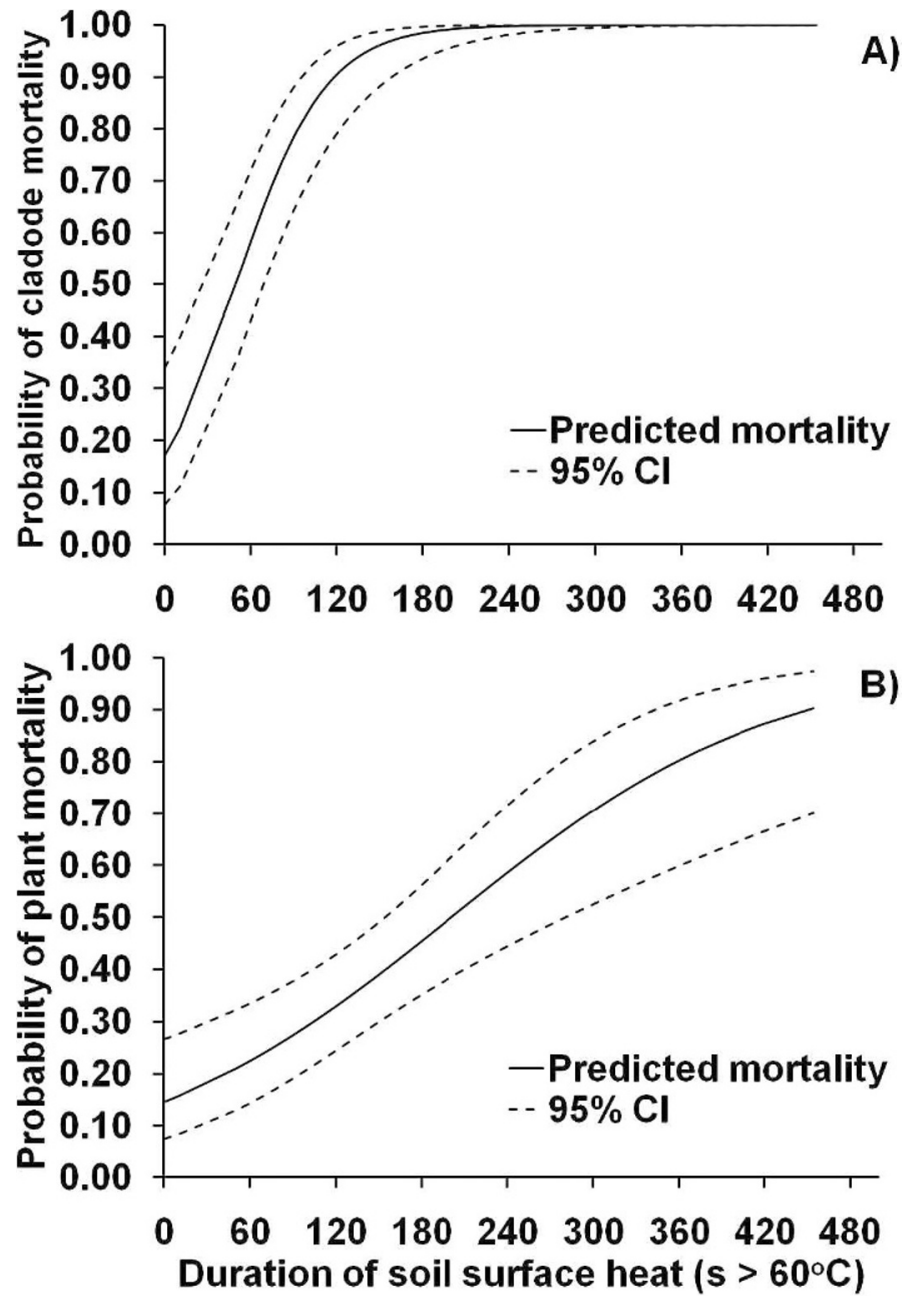

Figure 1. Predicted mortality and $95 \%$ confidence intervals $(\mathrm{Cl})$ for a single original prickly pear cladode $(\mathbf{A})$ and the whole plant (B), including new sprouts of surviving plants, based on duration of fire-induced heat greater than $60^{\circ} \mathrm{C}$ at the soil surface.

of fuels could have reduced potential fuel moisture effects that may have occurred in the field with the two weather conditions, but we do not believe this was the case because others observed no fuel moisture effect on maximum temperature when fuel

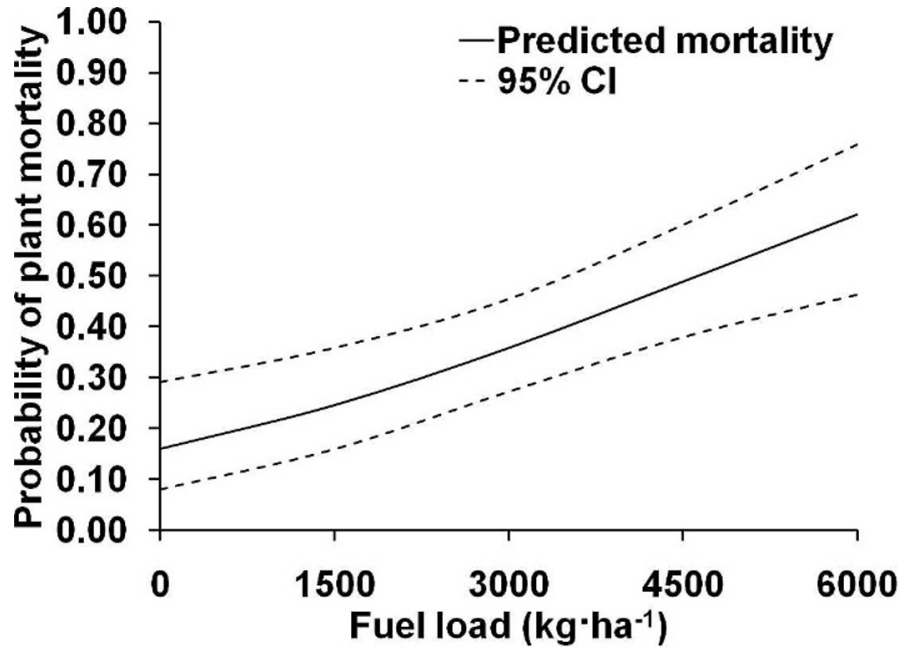

Figure 2. Predicted mortality and $95 \%$ confidence intervals $(\mathrm{Cl})$ for prickly pear plants, including new sprouts of surviving plants, based on fuel load.

moisture was 6-33\% (Britton and Wright 1971) and ours were $1.85 \%$ and $3.25 \%$ for moderate and severe conditions, respectively.

Greater differences in fire weather may have shown some effect. However, our moderate weather conditions were within limits commonly used for prescribed fire, and the severe conditions exceeded general guidelines for safe prescribed fire conditions. Hotter, drier conditions than our severe weather scenario would not likely be broadly utilized in a management context because of additional risks of fire escaping designated burn areas. Results indicate moderate fire weather conditions can produce similar levels of prickly pear control as severe fire weather conditions, given that fuels are readily combustible and in proximity to the cacti. In contrast, conditions supporting intense fires were more effective in controlling cactus than moderate conditions when cactus mottes were large and therefore limited fuel loads in interior portions (Ansley and Castellano 2007).

\section{Fuel Load and Heat Effects}

Fuel load was the greatest controlling factor for all measures of heat, and results support similar findings by others (Stinson and

Table 5. Logistic regression statistics for prediction of plant mortality from fuel load and measures of heat at the soil surface and $8 \mathrm{~cm}$ above soil. Hosmer-Lemeshow is a goodness-of-fit test of predicted and actual response from partitioned data where probabilities of a greater $\chi^{2}$ exceeding 0.05 indicate a good fit. Max rescaled $r^{2}$ is an index of the coefficient of determination. $C$ statistic ranges from 0.5 (random) to 1.0 (perfect discrimination on response) for all pairs of opposite response, so 0.9 means the model correctly assigned higher probability for $90 \%$ of all pairs.

\begin{tabular}{|c|c|c|c|c|c|c|}
\hline Predictor variable & Slope $^{1}\left(\beta_{x}\right)$ & Intercept $\left(\beta_{0}\right)$ & $P>\chi^{2}\left(H_{0}: \beta_{x}=0\right)$ & Hosmer-Lemeshow & Max rescaled $r^{2}$ & $C$ statistic \\
\hline Fuel load $\left(\mathrm{kg} \cdot \mathrm{ha}^{-1}\right)$ & 0.00036 & -1.6594 & 0.0003 & 0.7354 & 0.16 & 0.699 \\
\hline \multicolumn{7}{|l|}{ Soil surface } \\
\hline Duration $\left(\mathrm{s}>60^{\circ} \mathrm{C}\right)$ & 0.00881 & -1.7660 & $<0.0001$ & 0.6469 & 0.21 & 0.749 \\
\hline Maximum $\left({ }^{\circ} \mathrm{C}\right)$ & 0.00325 & -1.6283 & 0.0018 & 0.1819 & 0.12 & 0.677 \\
\hline Degree-seconds $\left({ }^{\circ} \mathrm{C} \cdot \mathrm{s}>60^{\circ} \mathrm{C}\right)$ & 0.000087 & -1.6537 & $<0.0001$ & 0.2536 & 0.21 & 0.746 \\
\hline \multicolumn{7}{|l|}{$8 \mathrm{~cm}$ above soil } \\
\hline Duration $\left(\mathrm{s}>60^{\circ} \mathrm{C}\right)$ & 0.01110 & -1.2157 & 0.0211 & 0.2799 & 0.06 & 0.636 \\
\hline Maximum $\left({ }^{\circ} \mathrm{C}\right)$ & 0.00286 & -1.3247 & 0.0101 & 0.5458 & 0.06 & 0.640 \\
\hline Degree-seconds $\left({ }^{\circ} \mathrm{C} \cdot \mathrm{s}>60^{\circ} \mathrm{C}\right)$ & 0.000069 & -1.0129 & 0.0287 & 0.6706 & 0.08 & 0.645 \\
\hline
\end{tabular}

${ }^{1}$ Probability of mortality $=e^{\left(\beta_{0}+\beta_{x}\right)} /\left(1+e^{\left(\beta_{0}+\beta_{x}\right)}\right)$. 


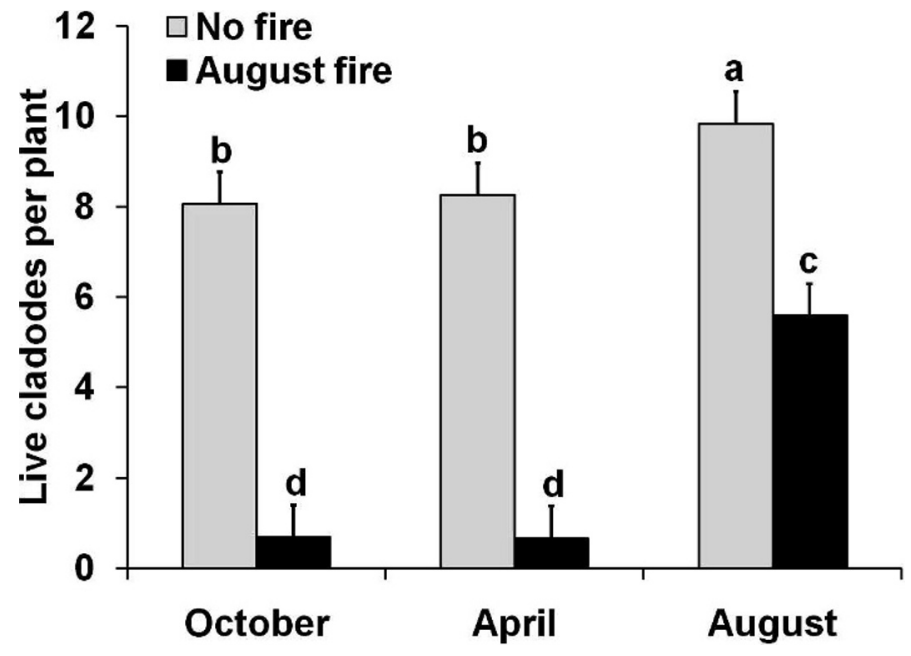

Figure 3. Number of live cladodes per prickly pear plant in nonburned and burned 0.75-ha plots 2, 8, and 12 mo following August fires. Means with the same letter do not differ $(\alpha=0.05)$.

Wright 1969; Britton and Wright 1971; Morgan 1999; Vermeire and Rinella 2009). Temperature readings from the burn cage were within ranges of field-collected data from temperate grasslands of southeast Australia (Morgan 1999), southern mixed prairie (Stinson and Wright 1969), and Florida sandhills (Gibson et al. 1990). Maximum temperatures were hotter than observed by Vermeire and Rinella (2009) with similar burn cage fuel treatments, but cooler ambient temperatures and greater relative humidity.

Fire at any fuel load reduced survival of original cladodes and live mass. Results indicate a threshold fuel load between 1500 and $3000 \mathrm{~kg} \cdot \mathrm{ha}^{-1}$ for survival and live mass of original cladodes and total live mass because of the similarity of fire effects among fuel loads equal to or greater than $3000 \mathrm{~kg} \cdot \mathrm{ha}^{-1}$ and the fact that those effects were greater than those at $1500 \mathrm{~kg} \cdot \mathrm{ha}^{-1}$ (Table 2). Achieving such fuel loads would require stockpiling of fuel or timing fire to follow productive growing seasons for many semiarid and arid regions. Testing cactus response to fuel loads at a finer scale may improve development of fuel load-based fire prescriptions.

Probability of mortality for individual cladodes and plants increased with fuel load and each measure of heat as hypothesized. That each measure of heat was related to mortality of individual cladodes and prickly pear plants was expected because all of the heat measurements were correlated with each other and driven by fuel load. However, duration of heat greater than $60^{\circ} \mathrm{C}$ was clearly the best predictor of prickly pear mortality as hypothesized. Others have indicated duration of heat was an important factor controlling fire-induced mortality (Wright 1970; McDaniel et al. 1997) and was closely related to fuel load (Engle et al. 1989; Morgan 1999). Lethal heat dosage is controlled by the interaction of temperature and exposure time (Wright 1970). Better explanation of plains prickly pear mortality by duration of heat than maximum temperature suggests fire temperatures were generally adequate to damage tissue and reflect that relative changes with increasing fuel load were greater for duration of heat than maximum temperature.
Time required to transfer heat through fuels is affected by fuel size, shape, and the surface-to volume ratio (Pyne et al. 1996). The lack of cladode weight, thickness, area, or surfaceto-volume ratio effects on plant response was therefore surprising. Morphological measures may become important for cladodes outside the range of morphological data we observed, but the range of data was considerable and included sizes most often encountered in the field. If morphological characteristics were important, our data indicate they would only be a factor with heat dosages less than those observed with $3000 \mathrm{~kg} \cdot \mathrm{ha}^{-1}$ fuel loads and possibly less than those produced with $1500 \mathrm{~kg} \cdot \mathrm{ha}^{-1}$ fuel loads.

\section{Burn Cage versus Field}

Exposure of a single cladode to fire may not represent the response of cactus mottes that can have hundreds of cladodes growing closely together. All cacti sampled in the field were multistemmed plants, and having an average of eight cladodes reduced the probability of mortality because all had to receive a lethal dosage of heat. Although fuel is often limiting within large cactus mottes (Ansley and Castellano 2007), fuel load was not substantially reduced for field cacti. Even so, some cladodes appeared to have been shielded from direct heat by neighboring cladodes. Prickly pear cladodes are commonly oriented to minimize surface area exposed to direct sunlight during the hottest part of the day (Rebman and Pinkava 2001). Therefore, the direction of the passing fire front may also affect exposure and survival of cladodes. However, it is not clear whether fire effects would be greater when the fire front is perpendicular to, as with the burn cage, or parallel with cladode orientation. The former would potentially maximize tissue exposure of cladodes on the leading edge of the fire front, but also maximize shielding of leeward cladodes. Burning parallel to cladode orientation would have the opposite effect.

Despite less plant mortality in the field, more cladodes were killed than may be expected from burn cage results, indicating postfire environment was important. Planting methods and postfire treatment each promoted favorable plant responses to fire for the burn cage experiment. Upright planting increases growth rate, dry weight, and cladode number (Singh and Singh 2003). Returning plants to the greenhouse immediately following fire protected fire-damaged plants from secondary disturbance, such as browsing, insect damage, freezing, or drought. Regular watering and temperatures were favorable for growth of new cladodes and survival of the original cladode. Such a watering structure kept cladodes well hydrated, which is an important variable in growth (Dougherty et al. 1996).

In contrast to burn cage plants, cacti in the field were exposed to a harsher postfire environment. Wildlife often browse prickly pear after fire (Stelfox and Vriend 1977; Courtney 1989), and burning is common practice in some regions to singe spines to promote livestock use (Shoop et al. 1977; McGinty et al. 1983). Although livestock did not have access to burned plots, pronghorn (Antilocapra americana), desert cottontails (Sylvilagus audubonii), and white-tailed jack rabbits (Lepus townsendii) were commonly observed and assumed responsible for the $83 \%$ of burned cladodes and $8 \%$ of nonburned cladodes being damaged. Damaged cladodes are also more susceptible to insect attacks and infestation (Wright 
1974; Bunting et al. 1980; Sickerman and Wangberg 1983). The effects of postfire browsing and insect damage may be greater than the direct fire effects, with mortality continuing to increase 2-4 yr following fire (Heirman and Wright 1973; Bunting et al. 1980; Martin 1983).

\section{IMPLICATIONS}

Plains prickly pear mortality was related to fuel load and all measures of heat. The best predictor of mortality was duration of heat greater than $60^{\circ} \mathrm{C}$. Because heat measures are often difficult to quantify during fire, fuel load could be a good metric for developing fire prescriptions. Fire at any fuel load reduced plains prickly pear, but a threshold was identified between 1500 and $3000 \mathrm{~kg} \cdot \mathrm{ha}^{-1}$, with live mass decreasing sharply between these fuel loads. Plains prickly pear were not uniquely acclimated to fire based on the soils where they originated. Variable responses of prickly pear across soils types would likely reflect changes in fuel load or fuel structure rather than ecological adaptation. Evidence was lacking in this study to suggest genetic adaptation to fire resistance based on longterm residence on a given soil type. Fire weather effects were minor despite considerable differences in ambient temperature and relative humidity. A gradient of wind effects was not evaluated but could be important to the extent that wind affects duration of heat. The lack of ambient temperature and relative humidity effects suggests prickly pear control can be achieved under broad fire prescriptions as long as the amount of combustible fuel is adequate. Sprouting of new cladodes under good field growing conditions indicated that a single fire is not likely to have long lasting effects on plains prickly pear populations. However, reduction in prickly pear with fire at any fuel load, increasing mortality of individual cladodes with increasing fuel loads, and additional damage to cacti following fire suggest prickly pear populations would be reduced by a sequence of fires or an approximation of natural fire regimes.

\section{LITERATURE CITED}

Ansley, R. J., and M. J. Castellano. 2007. Prickly pear cactus response to summer and winter fires. Rangeland Ecology \& Management 60:244-252.

Ansley, R. J., D. L. Jones, T. R. Tunnell, B. A. Kramp, and P. W. Jacoby. 1998. Honey mesquite canopy response to single winter fires: relation to herbaceous fuel, weather and fire temperature. International Journal of Wildland Fire 8:241-252.

Augustine, D. J., AND D. G. Milchunas. 2009. Vegetation response to prescribed burning of grazed shortgrass steppe. Rangeland Ecology \& Management 62:89-97.

Bement, R. E. 1968. Plains pricklypear-relation to grazing intensity and blue grama yield on central great plains. Journal of Range Management 21:83-86.

BEsSIE, W. C., AND E. A. Johnson. 1995. The relative importance of fuels and weather on fire behavior in subalpine forests. Ecology 76:747-762.

Britton, C. M., AND H. A. WRight. 1971. Correlation of weather and fuel variables to mesquite damage by fire. Journal of Range Management 24:136-141.

Bunting, S. C., H. A. Wright, and L. F. Neuenschwander. 1980. Long term effects of fire on cactus in the southern mixed prairie of Texas. Journal of Range Management 33:85-88.

Byram, G. M. 1959. Combustion of forest fuels. In: K. P. Davis [ED.]. Forest fire: control and use. New York, NY, USA: McGraw-Hill. p. 61-89.
Campbell, G. S., J. D. Jungbauer, W. R. Bidlake, and R. D. Hungerford. 1994. Predicting the effect of temperature on soil thermal-conductivity. Soil Science 158:307-313.

Campbell, G. S., J. D. Jungbauer, K. L. Bristow, and R. D. Hungerford. 1995. Soiltemperature and water-content beneath a surface fire. Soil Science 159:363-374.

Cook, C. W. 1942. Insects and weather as they influence growth of cactus on the central great plains. Ecology 23:209-214.

Courtney, R. F. 1989. Pronghorn use of recently burned mixed prairie in Alberta. Journal of Wildlife Management 53:302-305.

DeBano, L. F., D. G. Neary, and P. F. Ffolliott. 1998. Fire's effects on ecosystems. New York, NY, USA: John Wiley \& Sons. 333 p.

Dougherty, R. L., W. K. LAuenroth, AND J. S. Singh. 1996. Response of a grassland cactus to frequency and size of rainfall events in a North American shortgrass steppe. Journal of Ecology 84:177-183.

Engle, D. M., T. G. Bidwell, A. L. Ewing, and J. R. Williams. 1989. A technique for quantifying fire behavior in grassland fire ecology studies. Southwestern Naturalist 34:79-84.

Foxcroft, L. C., M. Rouget, D. M. Richardson, and S. MacFadyen. 2004. Reconstructing 50 years of Opuntia stricta invasion in the Kruger National Park, South Africa: environmental determinants and propagule pressure. Diversity and Distributions 10:427-437.

Freeman, D. B. 1992. Prickly pear menace in eastern Australia 1880-1940. Geographical Review 82:413-429.

Gibson, D. J., D. C. Hartnett, and G. L. S. Merrill. 1990. Fire temperature heterogeneity in contrasting fire prone habitats-Kansas tallgrass prairie and Florida sandhill. Bulletin of the Torrey Botanical Club 117:349-356.

GLendenIng, G. E. 1952. Some quantitative data on the increase of mesquite and cactus on a desert grassland range in southern Arizona. Ecology 33:319-328.

HART, R. H., AND M. M. AshBy. 1998. Grazing intensities, vegetation, and heifer gains: 55 years on shortgrass. Journal of Range Management 51:392-398.

HARVEY, A. D. 1936. Rootsprouts as a means of vegetative reproduction in Opuntia polyacantha. Journal of American Society of Agronomy 28:767-768.

Heirman, A. L., And H. A. Wright. 1973. Fire in medium fuels of west Texas. Journal of Range Management 26:331-335.

Hosmer, D. W., and S. Lameshow. 2000. Applied logistic regression. 2nd ed. New York, NY, USA: John Wiley \& Sons. 375 p.

Houston, W. R. 1963. Plains pricklypear, weather, and grazing in the northern great plains. Ecology 44:569-574.

KeELEY, J. E. 2009. Fire intensity, fire severity and burn severity: a brief review and suggested usage. International Journal of Wildland Fire 18:116-126.

Littell, R. C., G. A. Milliken, W. W. Stroup, and R. D. Wolfinger. 1996. SAS system for mixed models. Cary, NC, USA: SAS Institute. $633 \mathrm{p}$.

Lockwood, J. A., AND C. R. BomaR. 1992. Consumption of prickly pear cactus flowers by Melanoplus occidentalis-a coevolutionary association. Environmental Entomology 21:1301-1307.

Martin, S. C. 1983. Responses of semidesert grasses and shrubs to fall burning. Journal of Range Management 36:604-610.

McDaniel, K. C., C. R. Hart, and D. B. Carroll. 1997. Broom snakeweed control with fire on New Mexico blue grama rangeland. Journal of Range Management 50:652-659.

McGinty, A., F. E. Smeins, and L. B. MerRill. 1983. Influence of spring burning on cattle diets and performance on the Edwards plateau. Journal of Range Management 36:175-178.

Menard, S. 2002. Applied logistic regression analysis. 2nd ed. Thousand Oaks, CA, USA: Sage Publications. $111 \mathrm{p}$.

Milchunas, D. G., W. K. Lauenroth, P. L. Chapman, and M. K. Kazempour. 1989. Effects of grazing, topography, and precipitation on the structure of a semiarid grassland. Vegetatio 80:11-23.

Morgan, J. W. 1999. Defining grassland fire events and the response of perennial plants to annual fire in temperate grasslands of south-eastern Australia. Plant Ecology 144:127-144.

Price, D. L., R. K. Heitschmidt, S. A. Dowhower, and J. R. Frasure. 1985. Rangeland vegetation response following control of brownspine pricklypear (Opuntia phaecantha) with herbicides. Weed Science 33:640-643. 
Pyne, S. J., P. L. Andrews, and R. D. Laven. 1996. Introduction to wildland fire. New York, NY, USA: John Wiley \& Sons. $769 p$.

Rebman, J. P., and D. J. Pinkava. 2001. Opuntia cacti of North America-an overview. Florida Entomologist 84:474-483.

Rebollo, S., D. G. Milchunas, and I. Noy-MeiR. 2005. Refuge effects of a cactus in grazed short-grass steppe. Journal of Vegetation Science 16:85-92.

Rebollo, S., D. G. Milchunas, I. Noy-Meir, and P. L. Chapman. 2002. The role of a spiny plant refuge in structuring grazed shortgrass steppe plant communities. Oikos 98:53-64.

Reyes-Aguero, J. A., J. R. Aguirre, and A. Valiente-Banuet. 2006. Reproductive biology of Opuntia: a review. Journal of Arid Environments 64:549585.

Russell, C. E., and P. Felker. 1987. The prickly-pears (Opuntia spp., Cactacae): a source of human and animal food in semi-arid regions. Economic Botany 41:433-445.

Shoop, M. C., E. J. Alford, and H. F. Mayland. 1977. Plains pricklypear is a good forage for cattle. Journal of Range Management 30:12-17.

Sickerman, S. L., AND J. K. WangBerg. 1983. Behavioral responses of the cactus bug, Chelinidea vittiger Uhler, to fire damaged host plants. Southwestern Naturalist 8:263-267.

Singh, R. S., AND V. Singh. 2003. Growth and development influenced by size, age, and planting methods of cladodes in cactus pear (Opuntia ficus-indica (L.) Mill.). Journal of the Professional Association for Cactus Development 5:47-54.

Smith, S. D., B. Didden-Zopfy, and P. S. Nobel. 1984. High-temperature responses of North American cacti. Ecology 65:643-651.

Snyman, H. A. 2005. A case study on in situ rooting proffles and water-use efficiency of cactus pears, Opundia ficus-indica and 0 . robusta. Journal of the Professional Association for Cactus Development 7:1-21.
Snyman, H. A. 2006. A greenhouse study on root dynamics of cactus pears, Opuntia ficus-indica and 0 . robusta. Journal of Arid Environments 65:529-542.

Sparling, J. H., and D. W. Smith. 1966. Temperatures of surface fires in jack pine barren. 2. Effects of vegetation cover wind speed and relative humidity on fire temperatures. Canadian Journal of Botany 44:1293-1298.

Stelfox, J. G., and H. G. VRiend. 1977. Prairie fires and pronghorn use of cactus. Canadian Field-Naturalist 91:282-285.

Stephan, K., M. Miller, and M. B. Dickinson. 2010. First-order fire effects on herbs and shrubs: present knowledge and process modeling needs. Fire Ecology 6:95-114.

Stinson, K. J., And H. A. WRIGHT. 1969. Temperatures of headfires in the southern mixed prairie of Texas. Journal of Range Management 22:169-174.

Thomas, P. A., And P. Goodson. 1992. Conservation of succulents in desert grasslands managed by fire. Biological Conservation 60:91-100.

Turner, G. T., And D. F. Costello. 1942. Ecological aspects of the pricklypear problem in eastern Colorado and Wyoming. Ecology 23:419-426.

Vermeire, L. T., and M. J. Rinella. 2009. Fire alters emergence of invasive plant species from soil surface-deposited seeds. Weed Science 57:304-310.

Vila, M., J. A. Burriel, J. Pino, J. Chamizo, E. Llach, M. Porterias, and M. Vives. 2003. Association between Opuntia species invasion and changes in land-cover in the Mediterranean region. Global Change Biology 9:1234-1239.

Weaver, J. E., and F. W. Albertson. 1940. Deterioration of midwestern ranges. Ecology 21:216-236.

Wright, H. A. 1970. A method to determine heat-caused mortality in bunchgrasses. Ecology 51:582-587.

WriGHT, H. A. 1974. Range burning. Journal of Range Management 27:5-11.

Wright, H. A., and A. W. Balley. 1982. Fire ecology: United States and southern Canada. New York, NY, USA: John Wiley \& Sons. 501 p. 